\title{
Your grant is what you eat
}

\section{Washington}

Nutritionists find themselves divided on the activities of United Sciences of America (USA) Inc. Founded just six months ago, USA intends to put some $\$ 1.2$ million a year into nutritional research; the trouble is that the company's profits come from "network marketing" of "revolutionary dietary supplements". Despite USA's distinguished scientific board, many experts are sceptical about the value of dietary supplements for the general population and object to USA's advertising.

USA was founded last year by Robert M. Adler, a telecommunications entrepreneur. Its promotional videos make much of the claimed scientific merit of USA's preparations; a slickly produced 1985 video features views of huge computer rooms where research data is stored, and brief shots of the covers of Nature and the New England Journal of Medicine. The scientific advisory board includes two Nobel prizewinners and other well-known medical researchers. Critics allege, however, that not enough is known about some of the ingredients to recommend dietary supplements.

In addition to a retainer (at least for some members), members of the scientific advisory board get first shot at USA's research awards. Two weeks ago, at a meeting at its Dallas headquarters, USA approved its first twelve awards totalling $\$ 600,000$, of which several went to board members. But the meeting also spawned disagreement among the advisory board on the company's use of members' names for endorsements. One member, Dr Alexander Leaf of Harvard Medical College, threatened to resign unless his name was removed from endorsements.

According to Dr Jeffrey Fisher, USA vice-president for product development, the company will eventually offer a nutritional plan, a weight management plan and an aerobic fitness plan. The catchword is "optimal health". So far only the nutritional plan is on the market: it consists of a preparation of vitamins, trace elements and amino acids billed as rich in anti-oxidants; a "fibre energy bar" that includes a complex mixture of carbohydrates and a proprietary blend of cotton seed and surimi protein; a calorie control formula, again with special proteins; and a marine lipid concentrate containing omega-3 fatty acids, antioxidants and garlic extract.

Many of the ingredients are the subject of legitimate research. But many nutritionists question the strength of the evidence on which USA's products are based. Some, such as Dr Robert Good of the University of Southern Florida, chairman of the scientific advisory board, be- lieve that indirect evidence is sufficient to recommend that the public take, for example, fish oils. But others, such as Henry Kamin of Duke University, who recently chaired a controversial National Research Council dietary study, believe that to offer fish oil supplements to the general public is "grossly premature".

Kamin - and many others - believes that epidemiological evidence (such as the low rate of heart disease among eskimos who eat a lot of fish) should not be used as a basis to "stuff people with fish oils" until possible hazards of long-term use are evaluated. Even if they could benefit some individuals, nobody has any idea of what would be a good dosage of omega fatty acids, according to Kamin. One of USA's recent research awards was to Leaf to investigate the effects of different levels of fish-oil supplements on blood chemistry.

Kamin also argues that there is no need for special protein blends with good amino-acid balance when the typical US citizen daily eats more than three times the amount necessary. He questions the relevance of the scientific advisory board's expertise; although a celebrity cast, few if any members are primarily nutritionists, a point admitted by Fisher.

Other features of the USA products are also contentious. Victor Herbert of Mount Sinai School of Medicine says there is "no evidence" that taking supplementary doses of vitamins $\mathrm{E}$ and $\mathrm{C}$ above national recommended daily allowances has any protective effect against cancer, a conclusion reached by the National Academy of Sciences in 1982.

USA's advertising is careful not to make any claims about specific health benefits, which would in the eyes of the Food and Drug Administration make the product a drug needing trials for safety and efficacy. But the 1985 video, which dwells darkly on environmental pollution and blames it for high heart disease and cancer rates, manages to suggest directly that USA's products might counter these hazards.

Leaf, chairman of the department of preventative medicine and clinical epidemiology at Harvard Medical College and a member of the scientific advisory board, is quoted in USA promotional materials as saying that "the four formulas of USA Inc. together constitute a nutritional plan that is the finest and most complete I have ever seen". But Leaf denies making such a statement and says he thought he had been "a little naive" in his dealings with USA Inc., having been told only that he would serve as a consultant. Leaf said he was threatening to resign from the advisory board unless his name was removed from product endorsements and that other members had made similar protests. The American Heart Association's logo is also apparently used in the video without permission.

USA's sales method is a source of concern to some. Described by Fisher as "as innovative as the programs", it involves individuals becoming "associates" of the company and then recruiting more associates - similar to "pyramid selling". The Food and Drug Administration points out that it is difficult to police claims made for products sold in private. But Dr Robert Morin of the University of California at Los Angeles, another member of the advisory board, contends that the instructional materials provided by USA Inc. make "network selling" preferable to simple counter sales.

Good says the dietary programme has been established "within conventional scientific wisdom" to provide "undernutrition without malnutrition". Good admitted that he had not seen USA's promotional video. But he is a believer in the benefits of anti-oxidants, which may inhibit some ageing processes. Good says he has been able to forestall death of genetically short-lived animals in all species so far studied, and believes there are sufficient data to promulgate cautiously dietary supplements to the public. And Good believes that a weight-reduction plan must include protein supplements.

Fisher admits that early videos were "too hypish" and says later versions were toned down. And he admits that there is debate about some nutrients in USA products but says science is coming around to USA's point of view.

Tim Beardsley

\section{Young Hungarian}

SzeGed University's Department of Natural Sciences has called on the Hungarian government to cut military spending and uneconomic large-scale projects and to devote the money saved to improving higher education and the standard of living of young graduates. Although such issues have been raised before in Hungary's underground press, this is the first time that they have been explicitly stated in an official context, at least since the discussions that led up to the $\mathbf{1 9 5 6}$ uprising.

The Szeged group, which consists of young academic and graduating students, submitted its proposals to the Congress of the Hungarian young communist movement in May. Officially they were ignored and, according to some unconfirmed reports, copies of the university newspaper, Szegedi Egyetem, which carried the proposals, have been impounded.

Even apart from the proposal that military spending should be "rationalized", the Szeged document is bound to be controversial. One proposal is that the univer- 